\title{
A Baseline Study On The Occurrence And Distribution of Microplastics In The Highly Polluted Metropolitan River Cooum, Chennai, India.
}

Velusamy Selva Ganapathy ( $\sim$ selvaganapathy03@gmail.com )

Sathyabama Institute of Science and Technology

Krishnamoorthy Radhakrishnan

University of Madras

Palanichamy Prakasheswar

University of Madras

\section{Research Article}

Keywords: Microplastic, Riverine Environment, Cooum River, Surface Sediment, Water, Pollution

Posted Date: October 1st, 2021

DOl: https://doi.org/10.21203/rs.3.rs-720731/v1

License: (c) (i) This work is licensed under a Creative Commons Attribution 4.0 International License.

Read Full License 


\section{Abstract}

The current research aimed to determine the distribution of micro plastics in surface sediments and water from Chennai's Cooum River. The fiber dominates the Cooum River's surface sediments and water, followed by beads and fragments. Both the sediment and the water contain a high concentration of $<1 \mathrm{~mm}$ size micro plastics. The distribution counts of micro plastics in the Cooum River are significantly low compare to those found in the St. River Lawrence and Amazon river brazil. The distribution of micro plastics in riverine environments is strongly influenced by waste water discharge from domestic and industrial sources, as well as waste dumping near riverbanks.

\section{Introduction}

Due to its low cost, durability, and versatility, the invention of plastic revolutionized the entire globe. Plastics are engineered polymers that are used in a wide range of human applications and have become an indispensable element of our daily life (Hammer et al., 2012). Since the early part of use, the contamination of our environment by micro plastic has also begun. Studies on plastic pollution in the marine environment began in the late 1970s (Carpenter and Smith, 1972); since then, research on plastic contamination has increased, with major studies focusing on aquatic environments such as lakes, rivers, and deep-sea sediments (Carpenter and Smith, 1972; Cózar et al., 2014; Eerkes-Medrano et al., 2015).

Plastics which are less than $5 \mathrm{~mm}$ are termed a micro plastic (Thompson et al., 2009; NOAA 2015) categorized into primary and secondary based on their origin. Primary micro plastics are intently manufactured in the size of less than $5 \mathrm{~mm}$ have a varied use in the field of medicine, textile and cosmetic industry (Fendall and Sewell, 2009; Eriksen et al., 2013; Bergmann, et al., 2015).

Secondary micro plastics are produced as a result of the degradation of larger plastics (Thompson et al., 2009), and both types enter the ecosystem solely through domestic and industrial discharge. Due to prolonged exposure to sunlight and climate, micro plastic fibres originating from land-based activities disintegrated quickly (Cooper and Corcoran, 2010). Plastics' low recycling rate contributes significantly to the emergence of micro plastics. Micro plastics pose a risk to the aquatic environment because of their long residence duration, the possibility of biota ingesting them, and the emission of harmful components during degradation.

Microplastics enter the food chain of higher organisms through phytoplankton in both the marine and fresh water environments (Moore et al. 2002). Micro plastic has made its way into soils, groundwater via percolation, rivers via discharge, and fish and molluscan tissues due to its tiny size (A.L.Lusher et al., 2012; Anika Ballent, et al., 2016; Naidu et al., 2018). According to a Central Pollution Control Board (CPCB) survey conducted in 2015 across 60 cities in India, 15,342 tonnes of plastic waste is generated per day, of which $60 \%$ is recycled and the rest is landfilled (Aryan et al., 2018).

The factors affecting the distribution of the micro plastics are density, shape (fibers, fragments and pellets), size, (Eerkes-Medrano et al., 2015) wind, geostrophic circulation and water flux (Law et al., 2010; 
Ballent et al., 2012; Turra et al., 2014). The aim of this research is to assess the distribution of microplastics in surface water and sediment in Chennai's Cooum River.

\section{Study Area}

Cooum is a non-perennial river that originates at a dam in Kesavaram, which is about 48 kilometers west of Chennai. During the monsoon season, the excess water from the cooum tank is the primary source of water in that river. Agriculture dominated the banks of the Cooum in its upper reaches, but as it neared the Vanagram, the river began to be polluted by the discharge of domestic and industrial waste and the flow of the river is almost nil in the city limits. It flows through Kanchipuram, Thiruvallur, and Chennai districts for approximately 68 kilometers before entering the sea, Bay of Bengal.

\section{Methodology}

Systematic sampling was carried out to collect the 15 surface sediments and water samples the Cooum River at one-kilometer intervals. The sampling locations were pre-fixed using ARC-GIS 10.3, and the resulting kml data was superimposed on Google maps with use of LOCUS MAP (Free version 3.50.1) Hiking GPS navigation and map software tracking the sampling locations. For accuracy, the coordinates were cross-checked with the GPS in the field. The sediment samples were collected using a Van-Veen grab sampler. The sediment samples were packed in glass bottles (to avoid contamination) with a metal lid labeled with the sampling location. One liter of water samples were taken in pre-cleaned glass bottles with metal lids in the same area where the sediments were collected.

Wet sediment samples were oven dried at $60^{\circ} \mathrm{C}$ and sieved through $5 \mathrm{~mm}$ mesh to remove coarser plastics while retaining finer ones. To remove organic matter and calcareous debris, sieved samples were coned and quartered, and $30 \mathrm{~g}$ of sediments were treated with $30 \%$ hydrogen peroxide $\left(\mathrm{H}_{2} \mathrm{O}_{2}\right)$ and $2 \mathrm{~N} \mathrm{HCL}$. The extraction procedure of micro plastic was followed as per (NOAA, 2015). The pre-treated riverine sediment samples were mixed with $50 \mathrm{ml}$ of zinc chloride solution (density of $1.55 \mathrm{mg} / \mathrm{cm} 3$ ) and passed through $0.45 \mu \mathrm{m}$ nitrocellulose membrane filter paper (Whatsman®) using a vacuum pump. The filter paper and vacuum pump assembly are used for the filtration procedure on the water samples. Each sediment and water sample undergoes the filtration procedure twice to ensure accuracy. The filter paper then be carefully placed in the perish dish (marked with sampling locations) and allowed to dry before being examined for micro plastic distribution using an optical stereo zoom microscope. To avoid contamination from an external source (air), all laboratory analyses were meticulously monitored. To avoid sample contamination, the glassware used for the analysis was rinsed with the distilled water and wiped with ethanol.

Under the NIKON SMZ25 optical stereo zoom microscope attached to the camera, the extracted micro plastic was sorted by color, size, and shape. A pie-chart depicts the concentration and distribution percentage of micro plastics. Microsoft Excel 2010 was used to create the graphical diagrams. 


\section{Result And Discussion}

This study found total of 342 micro plastics in sediments and 89 micro plastics in the water samples. In sediments the maximum concentration of micro plastics of 37 counts was observed in the sampling location 4. In water samples the maximum concentration of 15 counts was observed in the sampling location 3. Table: 1 Data from the current study and data from other rivers throughout the world were compared.

\section{Color}

Micro plastics were separated into two groups as Colored and White for the color classification (Radhakrishnan et al., 2021). Almost 69 percent of the micro plastics in the sediments were colored, while the remaining 31 percent were colorless. In water samples, $68 \%$ of the micro plastics were colored, while $32 \%$ were colorless (Fig. $3 \mathrm{c} \& 3 \mathrm{~d}$ ). Colored micro plastics were abundant in both the sediment and the water at the sample site 431 \& 12 counts (Fig: $3 a$ \&3b). This data shows that colored micro plastics dominate in the sediment and water of the Cooum River.

\section{Size}

Thompson et al., (2004) explained the size of the micro plastics is greatly affected by the disintegration process (wave action, UV light, wind, etc.). The size distribution (Fig: 4c\&4d) of micro plastics in Cooum River sediment and water is as follows: $<1 \mathrm{~mm}$ (56\%), 1-3mm (28\%) 3-5mm (16\%) and $<1 \mathrm{~mm}(45 \%), 1$ $3 \mathrm{~mm}(25 \%), 3-5 \mathrm{~mm}$ (30\%). Plastics with a size of $<1 \mathrm{~mm}$ predominated in both the sediment and the water of the Cooum River. The highest concentration of micro plastic with a size of $1 \mathrm{~mm}$ is found in sample 4 of both water and sediments. Sample 9 has the highest concentration of micro plastics with a size range of $1-3 \mathrm{~mm}$ in sediments, while sample 10 has the highest concentration in water. Sample 9 has the highest concentration of micro plastics ranging in size from $3-5 \mathrm{~mm}$ in both sediment and water (Fig: 4a\&4b).

\section{Shape}

Micro plastics are classified into four types: fibers, fragments, films, and pellets (Doyle et al., 2011). The sediments were dominated by fibers ( $86 \%)$, followed by beads $(6 \%)$, and fragments $(8 \%)$. In Water, fibers were the most prevalent in total distribution, accounting for (87\%) of the total, followed by beads (8\%), and fragments (5\%) (Fig: 5c\& 5d). Sample 4 had the highest concentration of fibers and beads, while sample 3 had the highest concentration of fragments in sediments. Sample 4 has the highest concentration of fibers in water, while sample 3 has the highest concentration of beads and the sample 14 has the highest concentration fragments (Fig: $5 a \& 5 b$ ). Microplastics in the form of fibres and fragments may be discharged indirectly from secondary sources as a result of the disintegration of larger 
plastic particles caused by photo catalytic breakdown, oxidation, and/or mechanical weathering (Andrady, 2011).

\section{Conclusion}

The research highlights the spatial distribution of micro plastics in surface sediments and water from Chennai's Cooum River. The distribution of micro plastics in the Cooum River is heavily influenced by domestic waste dumping near the river's banks and the discharge of untreated waste water from industries. Enforcing strong policies on the use of plastics, increasing exposure about the negative impact of micro plastics on the environment, and recycling plastics could all help to solve this problem.

\section{Declarations}

Ethics approval and consent to participate

Not applicable

Consent for publication

Not applicable

Availability of data and materials

Not applicable

Competing interests

No Competing interests

Funding

No funding's received from funding agency to carry out the work

Author's contributions

Velusamy Selva Ganapathy: Conceptualization, Writing - original draft.

Krishnamoorthy Radhakrishnan: Methodology, Software, Validation \& Data curation.

Palanichamy Prakasheswar Methodology, Software, Validation \& Data curation.

\section{References}


1. Andrady AL (2011) Microplastics in the marine environment. Mar Pollut Bull 62(8):1596 -1596 382 1605

2. Anika Ballent PL, Corcoran O, Madden PA, Helm, Fred J, Longstaffe (2016) Sources and sinks of micro plastics in Canadian Lake Ontario near shore, tributary and beach sediments Marine Pollution Bulletin. http://dx.doi.org/10.1016/j.marpolbul.2016.06.037

3. Crew A, Gregory-Eaves I, Ricciard A (2020) Distribution, abundance, and diversity of micro plastics in the upper St. River Lawrence. Environmental Pollution https://doi.org/10.1016/j.envpol.2020.113994

4. Aryan Y, Yadav P, \&Samadder SR (2019) Life Cycle Assessment of the existing and proposed plastic waste management options in India: A case study. J Clean Prod 211:1268-1283

5. Ballent A, Purser A, de Jesus Mendes P, Pando S, Thomsen L (2012) Physical transport properties of marine micro plastic pollution. Bio geo sci. doi:10.5194/bgd-9-18755-2012

6. Barnes DKA, Walters A, Gonçalves L (2010) Macroplastics at sea around Antarctica. Mar Environ Res 70(2):250e252. https://doi.org/10.1016/j.marenvres.2010.05.006

7. Bergmann M, Gutow L, Klages M (2015) Marine Anthropogenic Litter. Springer International Publishing, Cham, pp 229e244. DOI:10.1007/978-3-319-16510-3

8. Carpenter EJ, Smith KL Jr (1972) Plastics on the Sargasso Sea surface. Science 175:1240-1241

9. Cooper DA, Corcoran P (2010) Effects of mechanical and chemical processes on the degradation of plastic beach debris on the island of Kauai, Hawaii. Mar Pollut Bull 60:650-654

10. Cózar A, Echevarría F, González-Gordillo Jl, Irigoien X, Ubeda B, Hernández-León S, Palma AT, Navarro S, García-de-Lomas J, Ruiz A, Fernández-de-Puelles ML, Duarte CM (2014) Plastic debris in the open ocean. Proc. Natl. Acad. Sci. U. S. A. 111, 10239-10244.

http://dx.doi.org/10.1073/pnas.1314705111

11. Gerolin CR, Pupim FN, André Oliveira Sawakuchi ,Carlos Henrique Grohmann, Geórgia Labuto, Décio Semensatto (2020) Microplastics in sediments from Amazon rivers, Brazil Science of the Total Environment https://doi.org/10.1016/j.scitotenv.2020.141604

12. Doyle MJ, Watson W, Bowlin NM, Sheavly SB (2011) Plastic particles in coastal pelagic ecosystems of the Northeast Pacific ocean. Mar Environ Res 71:41-52

13. Eerkes-Medrano D, Thompson RC, Aldridge DC (2015) Microplastics in freshwater systems: a review of the emerging threats, identification of knowledge gaps and prioritization of research needs. Water Res 75:63-82

14. Eriksen M, Mason S, Wilson S, Box C, Zellers A, Edwards W, Farley H, Amato S (2013) Microplastic pollution in the surface waters of the Laurentian Great Lakes. Mar Pollut Bull 77(1-2):177-182

15. Fendall LS, Sewell MA (2009) Contributing to marine pollution by washing your face: microplastics in facial cleansers. Mar Pollut Bull 58(8):1225-1228. http://dx.doi.org/10.1016/j.marpolbul.2009.04.025

16. Wang G, Lu J, Tong Y, Liu Z, Zhou H, Nuerguli Xiayihazi (2021) Occurrence and pollution characteristics of microplastics in surface water of the Manas River Basin, China Science of The 
Total Environment https://doi.org/10.1016/j.scitotenv.2019.136099

17. Hammer J, Kraak MHS, Parsons JR (2012) In: Whitacre DM (ed), Reviews of Environmental Contamination and Toxicology. Springer New York, New York, pp 1e44

18. Li J, Ouyang Z, Liu P, Zhao X, Wu R, Zhang C, Lin C, Li Y, Guo X (2021) Distribution and characteristics of microplastics in the basin of Chishui River in Renhuai, China https://doi.org/10.1016/j.scitotenv.2021.145591

19. Law KL, Moret-Ferguson S, Maximenko NA, Proskurowski G, Peacock EE, Hafner J, Reddy CM (2010) Plastic accumulation in the North Atlantic sub- tropical gyre. Science 329

20. Lusher AL, Hugh MMc, Thompson RC (2012) Occurrence of microplastics in the gastrointestinal tract of pelagic and demersal fish from the English Channel Marine Pollution Bulletin https://doi.org/10.1016/j.marpolbul.2012.11.028

21. Moore CJ, Moore SL, Weisberg SB, Lattin GL, Zellers AF (2002) A comparison ofneustonic plastic and zooplankton abundance in southern California's coastal waters. Mar PollutBull 44:1035-1038

22. Muting Y, Nie H, Xu K, He Y, YH,Yumei Huang, Jun Wang, (2018). Microplastic abundance, distribution and composition in the Pearl River along Guangzhou city and Pearl River estuary, China Chemosphere https://doi.org/10.1016/j.chemosphere.2018.11.093

23. National Oceanographic and Atmospheric Administration (NOAA), (2015)A. Marine Debris Program: Types and Sources. Retrieved from http://marinedebris.noaa.gov/discover-issue/types-and-sources (on 3 December 2015)

24. Naidu SA, Rao VR, Ramu K (2018) Microplastics in the benthic invertebrates from the coastal waters of Kochi, Southeastern Arabian Sea. Environ Geochem HLTH 40(4):1377-1383

25. Singh N, Mondal A, Bagri A, Tiwari E, Khandelwal N, Monikh FA, Gopala Krishna Darbha (2020).Characteristics and spatial distribution of microplastics in the lower Ganga River water and sediment Marine Pollution Bulletin https://doi.org/10.1016/j.marpolbul.2020.111960

26. Prieskarinda Lestari Y, Trihadiningrum BA, Wijaya KA, Yunus M (2020) Firdaus Distribution of microplastics in Surabaya River, Indonesia Science of The Total Environment https://doi.org/10.1016/j.scitotenv.2020.138560

27. K.Radhakrishnana,VSivapriyaa, A.Rajkumara N.Akramkhan, PPrakasheswar, SKrishnakumar, SMHussain (2021) Characterization and distribution of microplastics in estuarine surface sediments, Kayamkulam estuary, southwest coast of India Marine Pollution Bulletin https://doi.org/10.1016/j.marpolbul.2021.112389

28. Thompson RC, Olsen Y, Mitchell RP, Davis A, Rowland SJ, John AW, McGonigle D, Russell AE (2004) Lost at sea- where is all plastic. Science 304:838

29. Thompson RC, Moore CJ, vom Saal FS, Swan SH (2009) Plastics, the environ- ment and human health: current consensus and future trends. Philos Trans R Soc Lond B Biol Sci 364(1526):2153e2166

30. Turra A, Manzano AB, Dias RJS, Mahiques MM, Barbosa L, Balthazar-Silva D, Moreira FT (2014) Three-dimensional distribution of plastic pellets in sandy beaches: shifting paradigms. Sci Rep 


\section{Table}

Table: 1 Comparative analysis of the current study's data with data from other rivers throughout the world

\begin{tabular}{|c|c|c|c|c|}
\hline Si.no & Sample & Concentration & Location & Reference \\
\hline 1 & \multirow{5}{*}{ Water } & $\begin{array}{l}1.47-43.11 \\
\text { particles } / \mathrm{m} 3\end{array}$ & Surabaya River, Indonesia & $\begin{array}{l}\text { Prieskarinda Lestari, et, } \\
\text { al., } 2020\end{array}$ \\
\hline 2 & & $\begin{array}{l}21 \pm 3-49 \pm 3 \\
\text { particles/L }\end{array}$ & Manas River Basin, China & $\begin{array}{l}\text { Gaoliang Wang, et, al., } \\
2021\end{array}$ \\
\hline 3 & & $\begin{array}{l}1.77-14.33 \\
\text { particles/L. }\end{array}$ & Chishui River, China & Jianlong Li, et, al., 2021 \\
\hline 4 & & $\begin{array}{l}8725-53,250 \\
\text { particles/m3 }\end{array}$ & Pearl River, China & Muting Yan, et, al., \\
\hline 5 & & 0-15particles/L & Cooum River, India & Current Study \\
\hline 6 & \multirow{4}{*}{ Sediments } & $\begin{array}{l}417-8178 \\
\text { particles /kg }\end{array}$ & Amazon rivers, Brazil & $\begin{array}{l}\text { Cristiano Rezende Gerolin, } \\
\text { et, al., } 2020\end{array}$ \\
\hline 7 & & $\begin{array}{l}65- \\
7562 \text { particles/kg }\end{array}$ & $\begin{array}{l}\text { Upper St. River Lawrence, } \\
\text { North America }\end{array}$ & Alex Crew, et, al., 2020 \\
\hline 8 & & 17-36 particles/kg & Lower Ganga River, India & Nisha Singh, et, al., 2020 \\
\hline 9 & & $\begin{array}{l}399-1232.1 \\
\text { particles/kg }\end{array}$ & Cooum River, India & Current study \\
\hline
\end{tabular}

Figures 


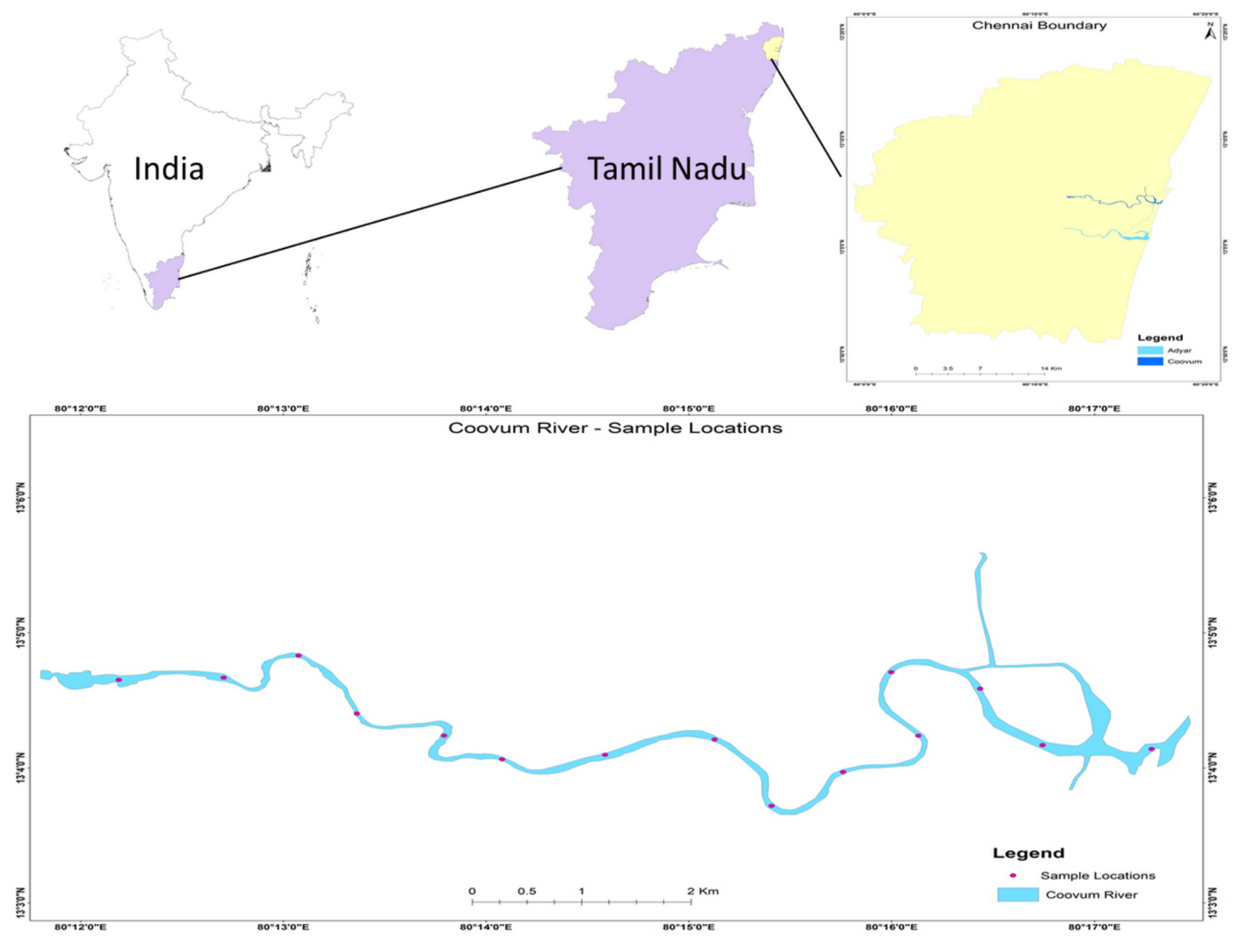

Figure 1

Sampling Locations in Cooum River 

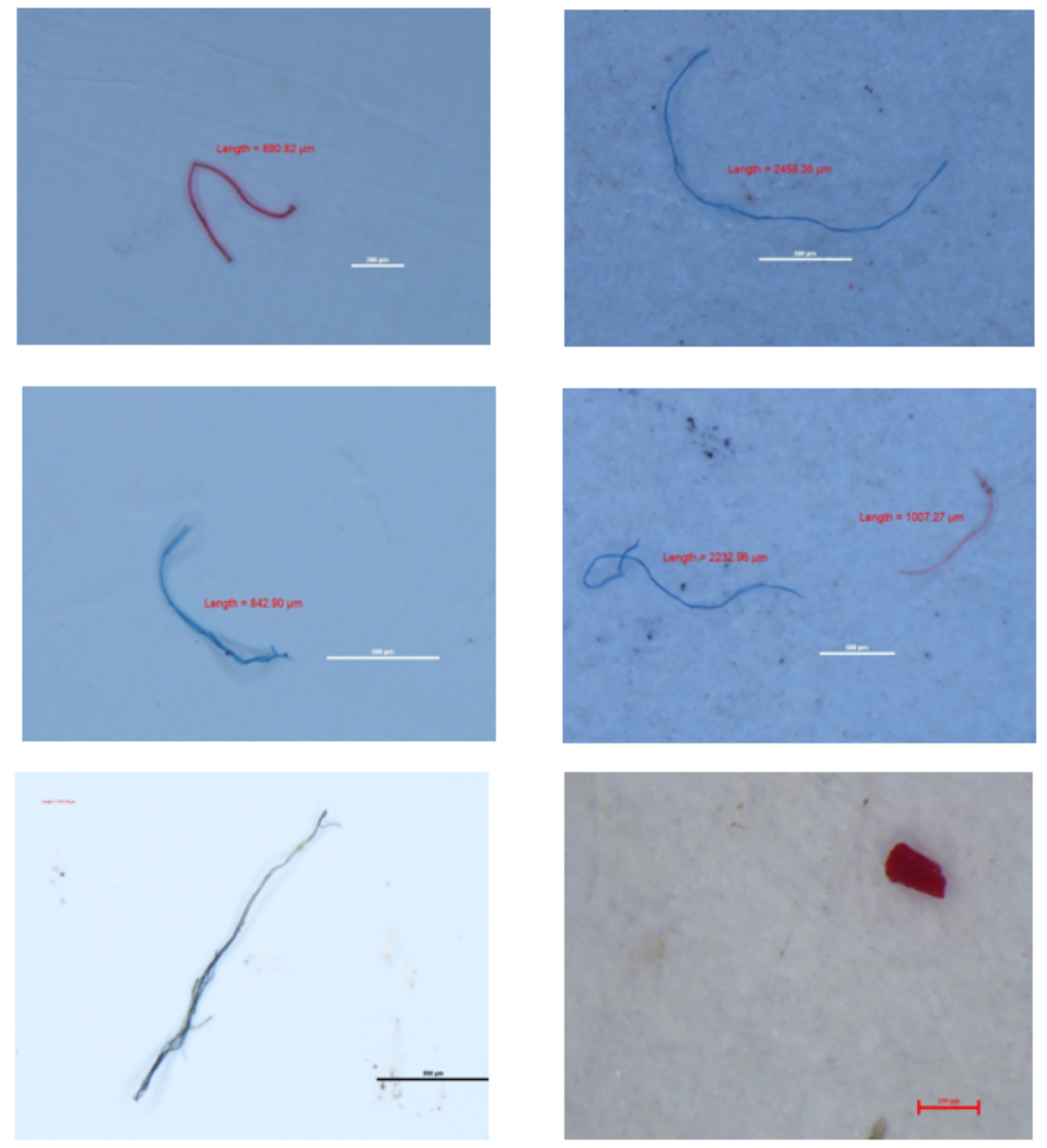

\section{Figure 2}

Microplastics from the Cooum River 


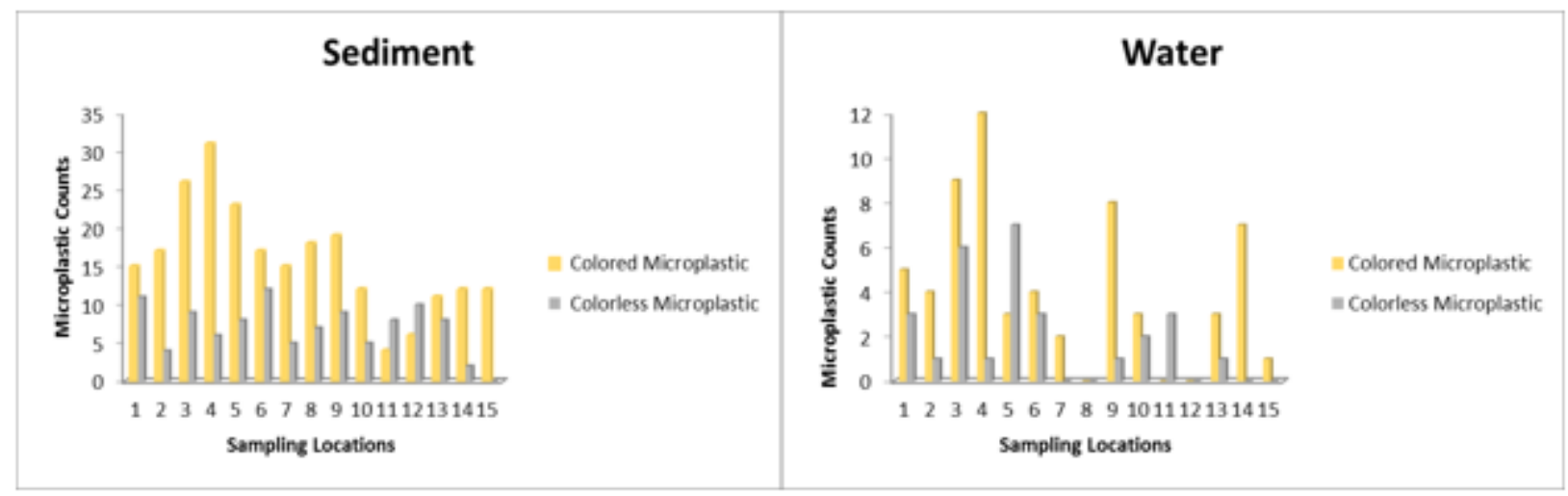

$3 \mathrm{a}$

$3 b$

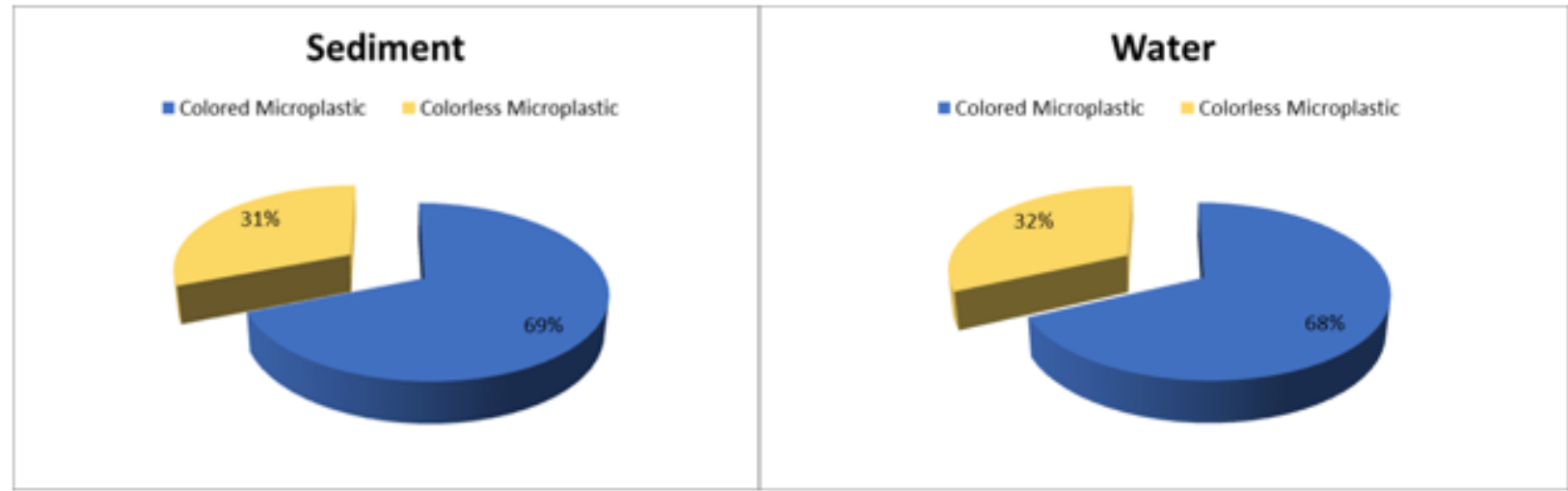

$3 c$

$3 d$

\section{Figure 3}

Color Classification of Micro plastics in, Cooum River 


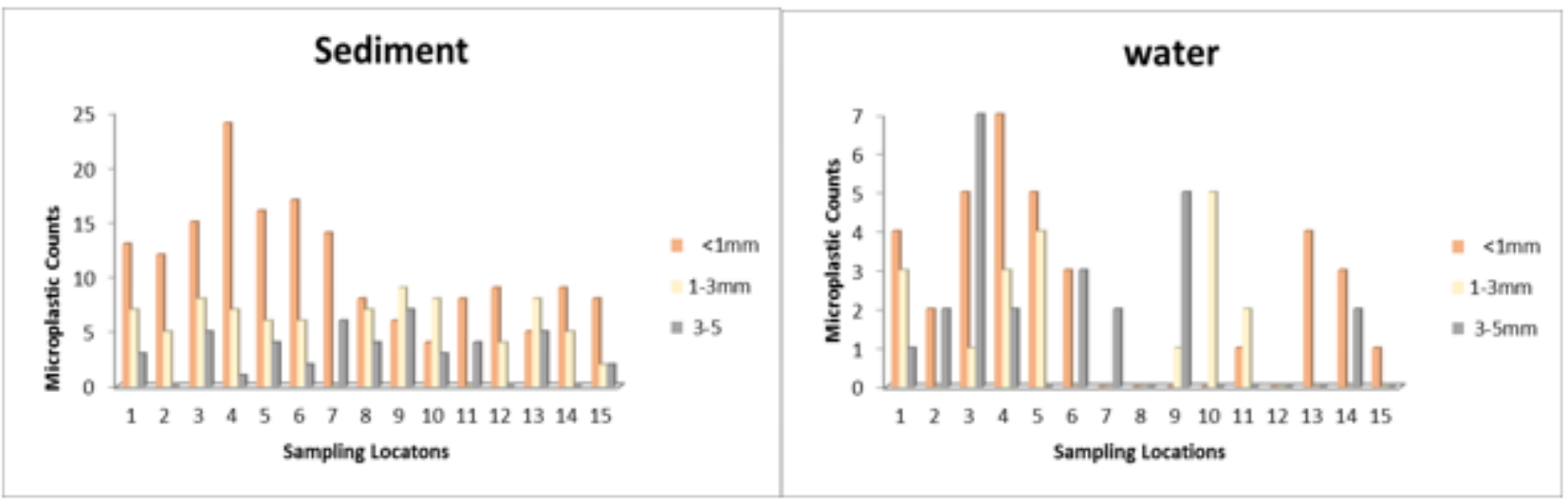

$4 a$

$4 \mathrm{~b}$

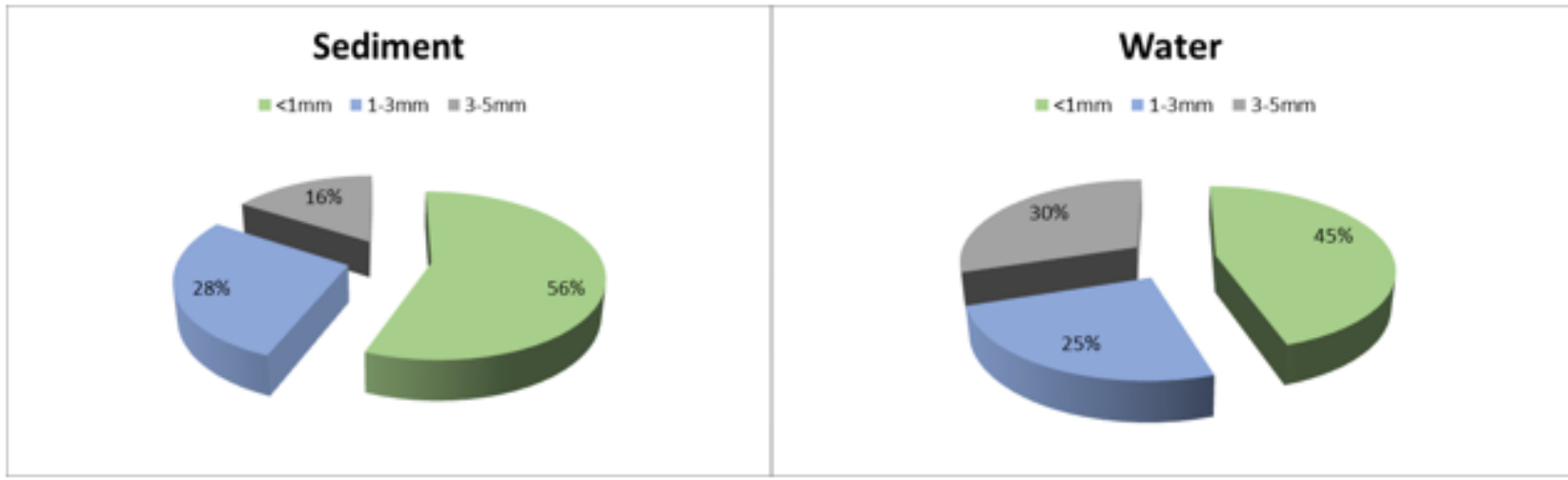

$4 c$

$4 d$

Figure 4

Size classification of Micro plastic in, Cooum River 


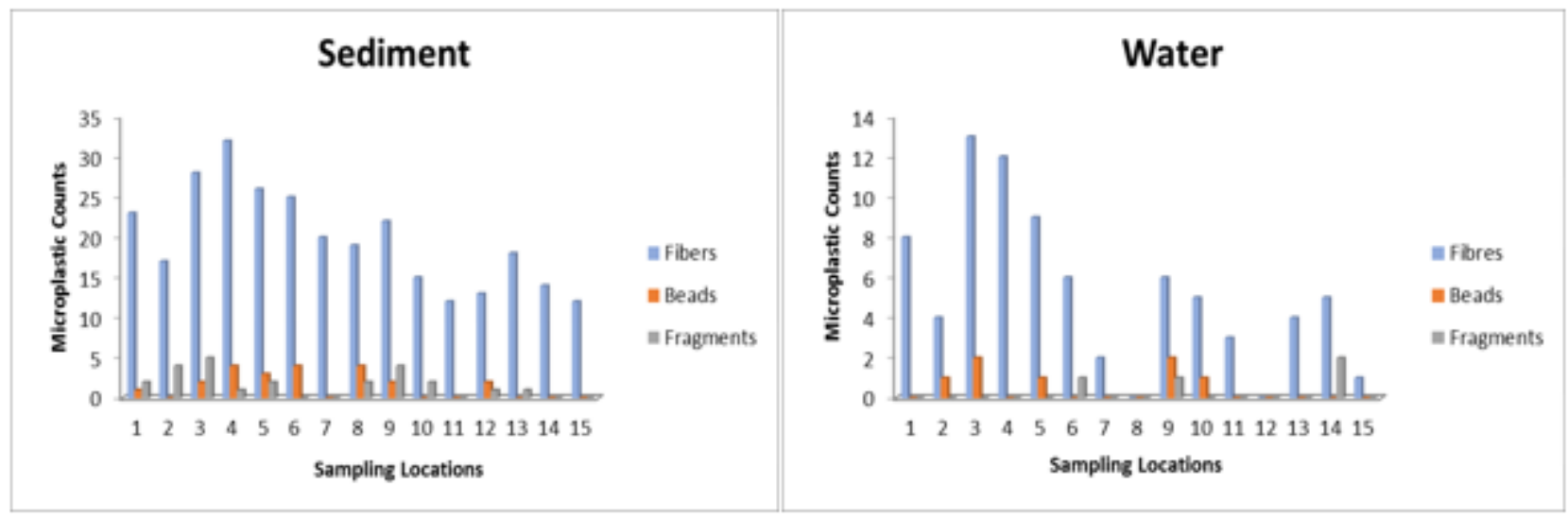

$5 \mathrm{a}-5 \mathrm{~b}$

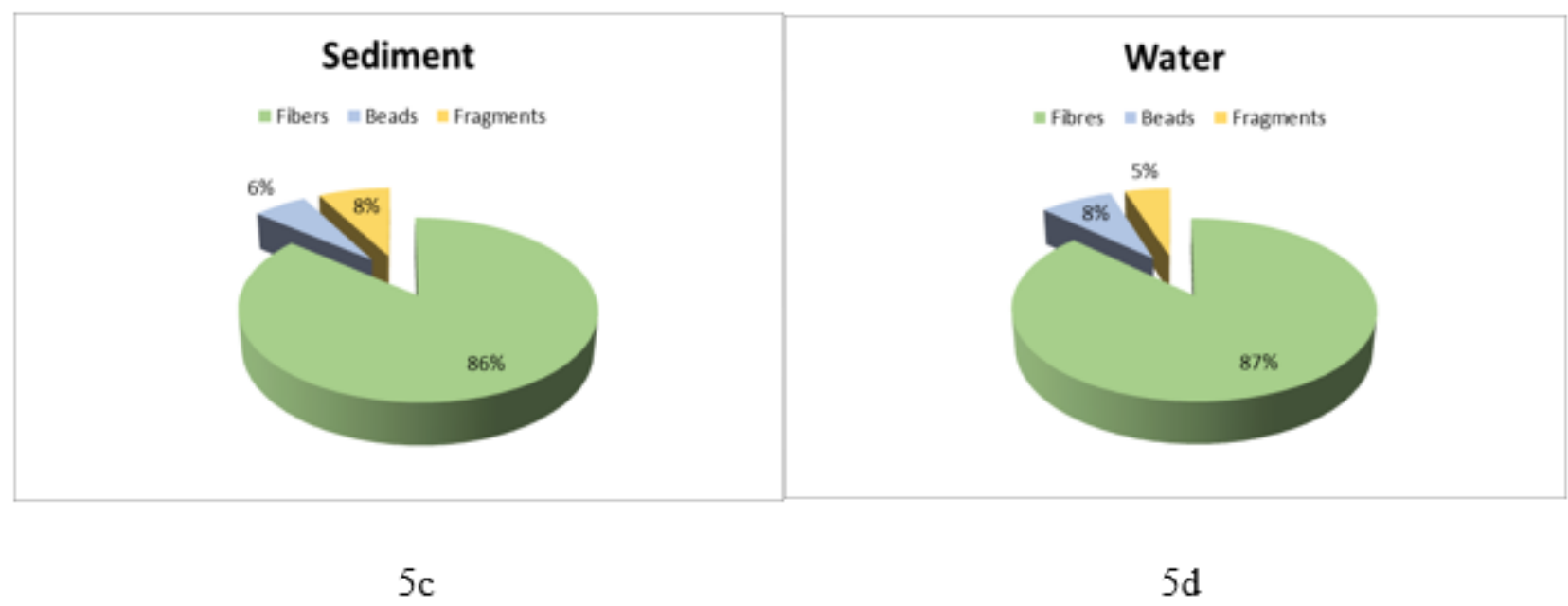

Figure 5

Shape classification of Micro plastic in, Cooum River. 